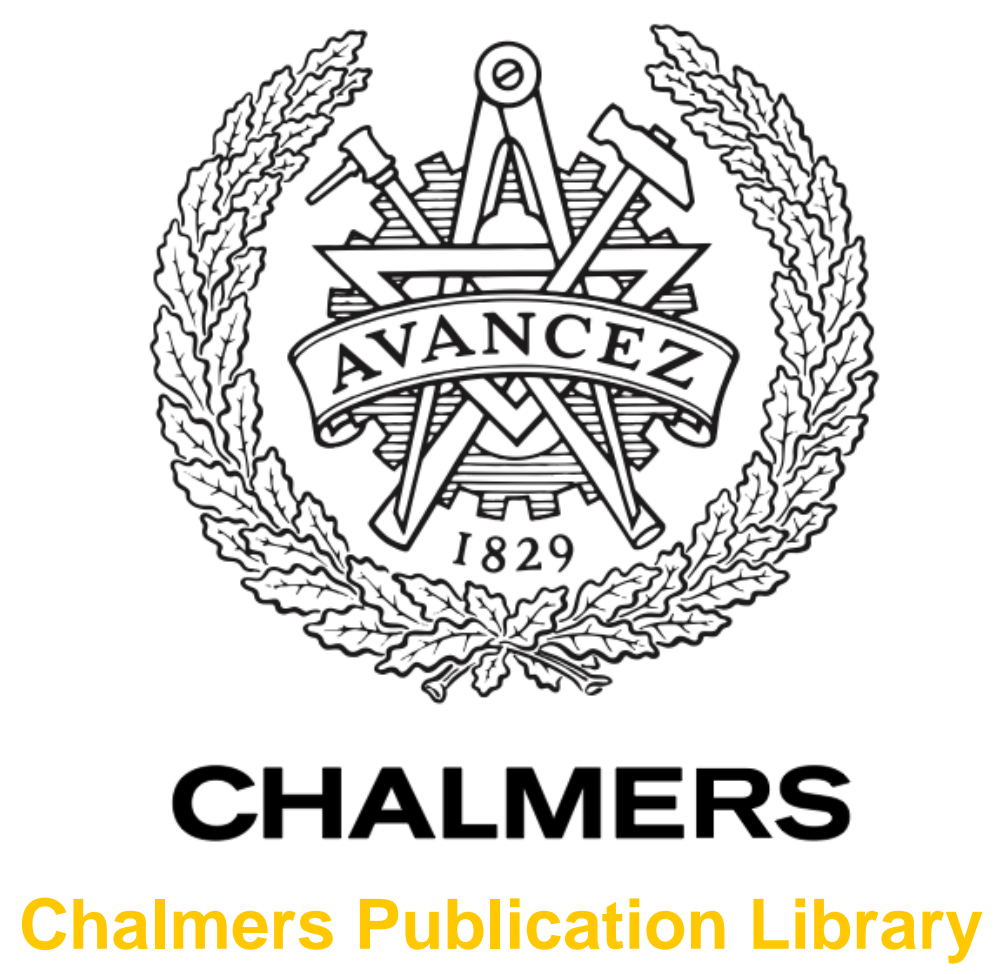

\title{
Measurement of the concentration of ammonia and ethene in the combustion chamber of a circulating fluidised-bed boiler
}

This document has been downloaded from Chalmers Publication Library $(\mathrm{CPL})$. It is the author's version of a work that was accepted for publication in:

Journal of the Institute of Energy

Citation for the published paper:

Åmand, L. ; Kassman, H. ; Karlsson, M. et al. (1997) "Measurement of the concentration of ammonia and ethene in the combustion chamber of a circulating fluidised-bed boiler".

Journal of the Institute of Energy(70), pp. 25-30.

Downloaded from: http://publications.lib.chalmers.se/publication/153567

Notice: Changes introduced as a result of publishing processes such as copy-editing and formatting may not be reflected in this document. For a definitive version of this work, please refer to the published source. Please note that access to the published version might require a subscription. 


\title{
Measurement of the concentration of ammonia and ethene in the combustion chamber of a circulating fluidised-bed boiler
}

\author{
L-E ÅMAND*, H KASSMAN**, M KARLSSON* and B LECKNER*
}

\begin{abstract}
This paper presents the results of measuring the ammonia and ethene concentration profiles in the combustion chamber of a circulating fluidised-bed boiler. The boiler was operated in three air-staging conditions with peat as fuel, and with the addition of lime. Two sampling techniques were used for the analysis of ammonia: gas-sampling probe connected to a Fourier transformed infra-red (FTIR) instrument, and a gas-quenching (GQ) probe where the sample was quenched directly in the probe tip by a trapper solution. Both techniques are accurate enough to distinguish the influence on air staging of the level of ammonia in the combustion chamber. Comparison of the concentration profiles for ammonia measured by the two procedures shows similar results. The levels of ammonia and ethene measured by FTIR follow each other in the combustion chamber for all three staging conditions. The FTIR spectra were evaluated by three methods: spectral subtraction, differential absorbance and the multiple variable analysis method named 'partial least square' (PLS). Almost equal levels of concentration of ammonia and ethene were found, regardless of the method employed. The measurement error from reactions with ammonia at the GQ probe tip was estimated in a simple model.
\end{abstract}

\section{Introduction}

$\mathrm{NH}_{3}$ and $\mathrm{HCN}$ are the major nitrogen-containing components released during pyrolysis and combustion of solid fuels. Both of them act as gas-phase precursors to the formation of $\mathrm{NO}$ and $\mathrm{N}_{2} \mathrm{O} . \mathrm{N}_{2} \mathrm{O}$ is preferentially formed from cyano species, and $\mathrm{NH}_{3}$-based compounds tend to react mainly to NO${ }^{1}$. These processes are not completely known, especially not in the complex environment of a fluidised bed; therefore measurements of the $\mathrm{NH}_{3}$ and $\mathrm{HCN}$ concentrations in the combustion chamber during combustion of different fuels can support prediction of the final emissions of $\mathrm{NO}$ and $\mathrm{N}_{2} \mathrm{O}$. Such results would be important, for instance, to support modelling of the nitrogen chemistry in real boilers $\mathbf{2 , 3}$. Another factor of environmental concern is the potential emissions of unburned volatiles, especially during combustion of highly volatile fuels such as peat and wood. Here $\mathrm{NH}_{3}$ and ethene are key components in volatiles conversion, representing nitrogen chemistry and hydrocarbons.

It is also important to measure $\mathrm{NH}_{3}$ during $\mathrm{NO}_{\mathrm{x}}$ abatement in low- $\mathrm{NO}_{\mathrm{x}}$ processes. In this case the goal is to find efficient ways of reducing $\mathrm{NO}$ with a minimal $\mathrm{NH}_{3}$ slip from the stack and without conversion of added reducing nitrogen species to HCN. For this reason much effort has been put into the development of analytical methods for determining $\mathrm{NH}_{3}$ and $\mathrm{HCN}$ in flue gases 4,5 and these new methods have been developed in parallel with established wet chemical methods 6 . After the development of a quenching probe, wet chemistry was used at higher temperatures in furnaces, such as in pulverised-coal combustion (PCC) $)^{7,8}$ and in fuel-oil flames 9 . The temperature in the combustion chamber of a CFB boiler is lower than in PCC, but the presence of particles and the complexity of the gas composition have the effect of complicating measurement. Also,

*Department of Energy Conversion; **Department of Inorganic Chemistry, Chalmers University of Technology and University of Gothenburg, S-41296, Sweden. in order to measure the true gas concentration in a combustion chamber with a sampling probe, the gases must be cooled rapidly to stop further reactions. Especially critical in a fluidised-bed combustion chamber is the passage through a particle filter in the probe tip. Secondary reactions could occur both in a filter cake and in the filter material itself.

Hitherto, measurements of $\mathrm{NH}_{3}$ and $\mathrm{HCN}$ profiles at temperatures of fluidised-bed combustors have been carried out in an entrained-flow reactor ${ }^{10}$ and in a laboratory CFB11. Furthermore, attempts to measure $\mathrm{NH}_{3}$ and $\mathrm{HCN}$ in the combustion chamber of the $12 \mathrm{MW} \mathrm{CFB}$ boiler at Chalmers have been made by Åmand 12 with a gas-sampling probe connected to a Fourier transform infra-red (FTIR) instrument and by Kassman et al13 with a gasquenching $(\mathrm{GQ})$ probe. The design of the GQ probe originated at the International Flame Research Foundation (IFRF), IJmuiden.

The purpose of the present project was to improve methods already applied in the combustion chamber of a CFB boiler ${ }^{12,13}$ and to compare the results from the two sampling techniques. The $\mathrm{NH}_{3}$ concentration profile was measured with the GQ probe previously used, but the GQ probe sampling system was improved to increase the measurement accuracy. There was a possibility that reactions with $\mathrm{NH}_{3}$ at the GQ probe tip ${ }^{13}$ could influence the result; therefore the measurement errors from these reactions were estimated by a simple model (which will be the subject of a later paper). The gas-concentration profile was also measured by means of the same equipment as in Ref.12, but the evaluation procedure was improved, as demonstrated by the determination of ammonia $\left(\mathrm{NH}_{3}\right)$ and ethene $\left(\mathrm{C}_{2} \mathrm{H}_{4}\right)$. Three methods of evaluating FTIR spectra are compared. Other gas components such as $\mathrm{HCN}$ will be treated elsewhere. The parallel $\mathrm{NH}_{3}$ measurements made possible a comparison between the concentration profiles obtained by the two techniques; the concentration profiles of the two volatile species ethene and ammonia in the combustion chamber measured by FTIR can also be compared: 


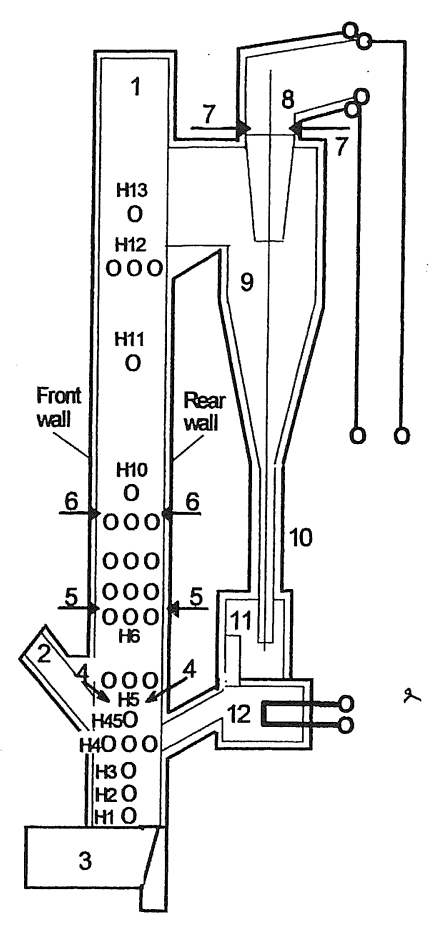

Fig.1 The 12-MW th CFB boiler at Chalmers University of Technology: (1) combustion chamber; (2) fuel feed chute; (3) air plenum; (4) secondary air inlet at $2.1 \mathrm{~m}$; (5) secondary air inlet at $3.7 \mathrm{~m}$; (6) secondary air inlet at $5.4 \mathrm{~m}$; (7) secondary air inlet into cyclone exit duct; (8) cyclone exit duct; (9) cyclone; (10) particle return leg; (11) particle seal; (12) heat-exchanger. Measurement ports $\mathrm{H} 1$ to $\mathrm{H} 13$ on the right-hand boiler wall are indicated.

\section{Experimental}

\subsection{The boiler}

The tests were performed in the $12 \mathrm{MW} \mathrm{CFB}$ boiler ${ }^{14}$ at Chalmers University of Technology. The measurement ports on the wall of the combustion chamber (Fig.1) are of particular interest in this project: they make it possible to sample gas inside the combustor and to characterise the combustion behaviour more closely. The boiler is equipped with on-line conventional flue-gas analysers for continuous monitoring of $\mathrm{O}_{2}, \mathrm{CO}, \mathrm{SO}_{2}, \mathrm{NO}$ and $\mathrm{N}_{2} \mathrm{O}$ in the stack, and of $\mathrm{O}_{2}, \mathrm{NO}, \mathrm{CO}, \mathrm{CO}_{2}, \mathrm{SO}_{2}, \mathrm{H}_{2}$ and total hydrocarbons ( $\mathrm{HC}$-tot) in the combustion gas from the gas-sampling probe.

\subsection{Operating conditions}

The measurements were performed in conjunction with a larger project concerning the influence of air supply on the emissions of $\mathrm{NO}, \mathrm{N}_{2} \mathrm{O}$ and $\mathrm{SO}_{2}{ }^{15,16}$. For this purpose the boiler was operated in three air-staging cases, and limestone was supplied at a molar ratio of 2.5:1 to 3:1 for sulphur capture. The fuel was peat of the following composition: ash $4 \%$, moisture $27 \%$ and content of combustibles $69 \%$, analysed as delivered; C 59\%, H 6.3\%, O 32\%, S 0.6\% and N $2.2 \%$, expressed on a moisture- and ash-free (maf) basis. The volatile content was $69 \%$ on the maf basis. Peat was supplied as cylinders of $30 \mathrm{~mm}$ diameter and up to $150 \mathrm{~mm}$ long; this shape was not maintained during the fuelhandling process, but large pieces of peat were still supplied to the boiler, and the production of fines was small.

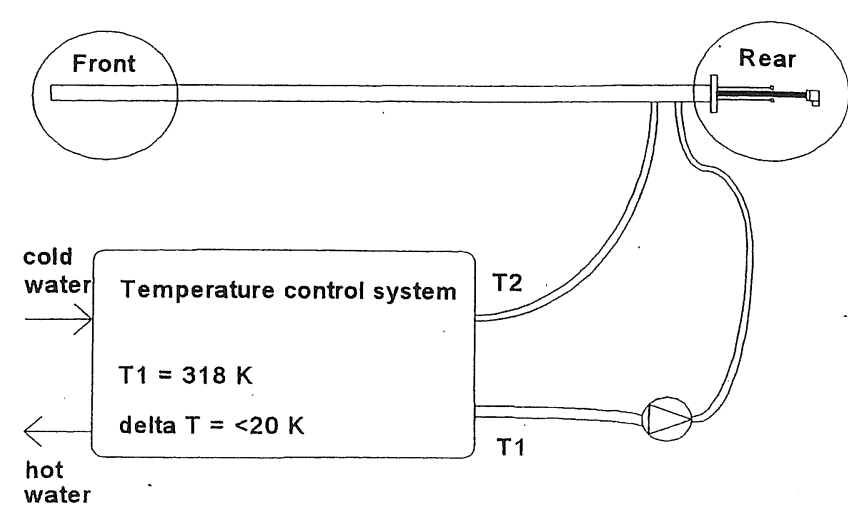

Fig.2a Gas-sampling probe used for analysis of hot gases from the combustion chamber.

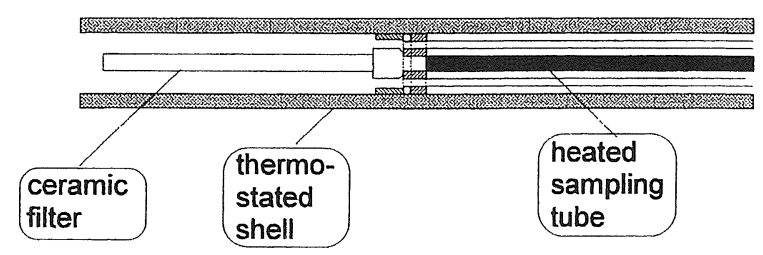

Fig. $2 \mathrm{~b}$ Front part of the gas-sampling probe.

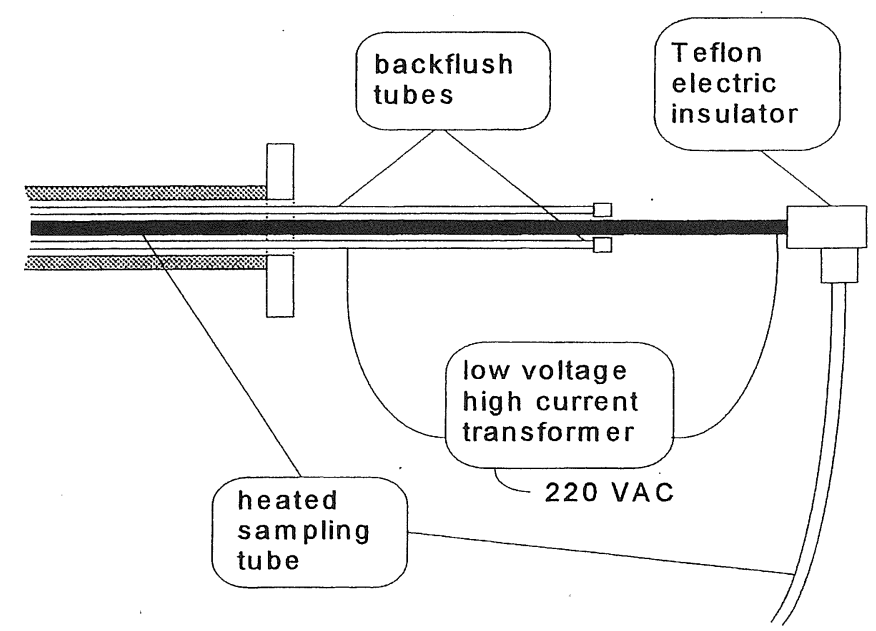

Fig.2c Rear part of the gas-sampling probe.

The air-staging 15 cases are:

Normal staging (reference case): $60 \%$ primary air and $40 \%$ secondary air (introduced $2.1 \mathrm{~m}$ above the air distributor).

No staging: no secondary air, all air added at the bottom of the combustion chamber, and the conditions were significantly more oxidising in the bottom part of the combustor relative to the refèrence case.

Reversed staging: no secondary air in the combustion chamber, but about $20 \%$ of the total air added downstream of the cyclone for final combustion. This meant less oxidising conditions in the upper part and more oxidising in the bottom part relative to the reference case. 


\subsection{The gas-sampling probe}

The probe shown in Fig.2a was designed for wet combustion gases; this is important in the analysis of $\mathrm{NH}_{3}$. Combustion gas first passes a ceramic filter mounted at the probe tip, Fig.2b, protected and cooled by the cooling shield of the probe. The gas is then transported through the centre pipe, which is electrically heated to $200{ }^{\circ} \mathrm{C}$, Figs. $2 \mathrm{~b}$ and $2 \mathrm{c}$. In order to control the temperature of the centre pipe the probe is water-cooled, Fig.2a, having a temperature of $45-95^{\circ} \mathrm{C}$. Downstream of the probe the combustion gas is transported to the gas analysers through heated gas lines. The ceramic filter is cleaned of ash and bed material by back-flushing with pressurised air at regular time intervals.

\subsection{The FTIR analyser}

The FTIR analyser is connected in series with the continuous gas analysers. The FTIR is a Bomem M110-D11 with a $500 \mathrm{~cm}^{3}$ quartz glass cell having an optical path-length of $3.6 \mathrm{~m}$. The instrument is equipped with an MCT detector. The maximum resolution of $4 \mathrm{~cm}^{-1}$ was used in all tests. The gas cell was heated to $200{ }^{\circ} \mathrm{C}$. The Spectra Calc software package 17 was used for evaluation and control of the spectrometer. During the present tests, spectra were collected in a continuous mode, where 28 mirror scans (each scan lasting approximately one second) were sampled for each single-beam spectrum stored. 27 stored single-beam spectra were added to form an average single-beam spectrum corresponding to a measurement time of about 15 minutes. An absorbance spectrum was produced from the ratio of this average spectrum and a reference spectrum ( $100 \%$ nitrogen) collected immediately before the sampling of the single-beam spectra. Three methods of evaluating spectra from FTIR were compared: spectral subtraction (SS), differential absorbance (DA) and a multiple variable analysis method named partial least square (PLS). Generally, the differences between the methods were small and did not affect the trends of $\mathrm{NH}_{3}$ and ethene in the combustion chamber, nor the absolute levels ${ }^{18}$.

\subsection{The gas-quenching (GQ) probe}

The GQ probe and the sampling system shown in Figs.3a and $3 b$ is described in detail by Kassman19. A sintered quartz filter (3b:1) attached to an uncooled steel pipe $(3 b: 2)$ in the probe tip, Fig. $3 b$, prevented particles contaminating the trapper solution injected through a distributor $(3 b: 3)$. Sampled combustion gas was withdrawn through the water-cooled quartz-lined (3a:2) probe. The acidic trapper solution (3a:4) was sprayed uniformly through the distributor into the tip of the quartz-lined suction line, to provide immediate gas quenching without losing any trapper solution. The trapper solution was circulated from a reservoir (3a:5) by a peristaltic pump (3a:3). The gas flow rate was 3-5 L/min, and a sampling time of about $15 \mathrm{~min}-$ utes gave a total gas volume of 50-80 litres. The total volume of gas withdrawn was measured by a mass-flow controller (3a:7) connected to a data-acquisition system, and a gas meter (3a:9) was used as a back-up. Each test was started and stopped in exactly the same procedure. The change of measurement port made it possible to collect any filter-cake on the probe tip. The amount of filter-cake during peat combustion varied with limestone addition, height above the nozzles and air-staging conditions. However, the appearance of the filter-cakes was similar.

\subsection{Analytical procedure}

The acidic $\left(1 \mathrm{mMol} \mathrm{dm}^{-3} \mathrm{H}_{2} \mathrm{SO}_{4}\right)$ trapper solution was analysed by means of both ion-selective electrodes (ISE) and distillation followed by titration ${ }^{13}$. The two methods gave similar concentrations of $\mathrm{NH}_{4}{ }^{+}$in the trapper solution. In the present project, the samples were analysed only with ISE, which permitted immediate preliminary analysis and evaluation to reconfirm the results before the measurement port was changed. In the evaluation the average $\mathrm{NH}_{3}$ concentration from a final accurate analysis of a reliable double sample was used. The concentration of $\mathrm{NH}_{3}$ in the combustion gas was calculated, assuming an absorption efficiency of $100 \%$ in the trapper solution. The calculation was performed by means of the ideal gas law together with the measured amount of gas that passed the mass-flow controller and the exact volume of trapper solution (approximately $250 \mathrm{ml}$ ).

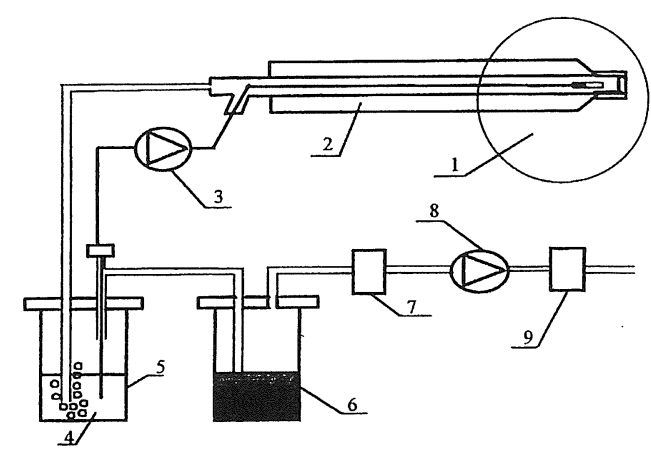

Fig.3a The gas-quenching (GQ) probe and the sampling system: (1) the tip of the probe (Fig.3b); (2) water-cooled quartz-lined probe; (3) peristaltic pump; (4) trapper solution; (5) reservoir; (6) dryer; (7) mass flow controller; (8) gas pump; (9) gas meter.

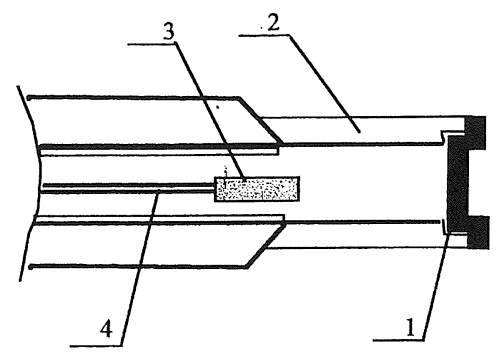

Fig. 3b The tip of the GQ probe: (1) sintered quartz filter; (2) uncooled steel pipe; (3) distributor; (4) injection line for the trapper solution. 


\section{Results}

\subsection{Measurement of ammonia and ethene concentrations}

The concentration profiles of $\mathrm{NH}_{3}$ and $\mathrm{C}_{2} \mathrm{H}_{4}$ measured by FTIR are plotted for the three air-staging cases in Figs. 4 and 5. In all cases, $\mathrm{NH}_{3}$ fell as a function of height above the bottom air nozzles in the combustion chamber. Fig. 6 shows a comparison of the three air-staging cases for the $\mathrm{NH}_{3}$ measurements with the GQ probe. The operating conditions have an impact on the measured levels of $\mathrm{NH}_{3}$ and $\mathrm{C}_{2} \mathrm{H}_{4}$, which can be distinguished with the evaluation methods used. No staging (which means more oxidising conditions in the lower part of the boiler) resulted in the lowest concentrations, except in the upper part of the combustion chamber. Relative to normal staging, both reversed and no-staging lead to a dilution effect caused by higher air flows in the lower part of the combustion chamber. Dilution could also explain the lower concentration values of $\mathrm{NH}_{3}$ and $\mathrm{C}_{2} \mathrm{H}_{4}$ for reversed and no staging (Figs. 4-6) in the lower part of the combustor.

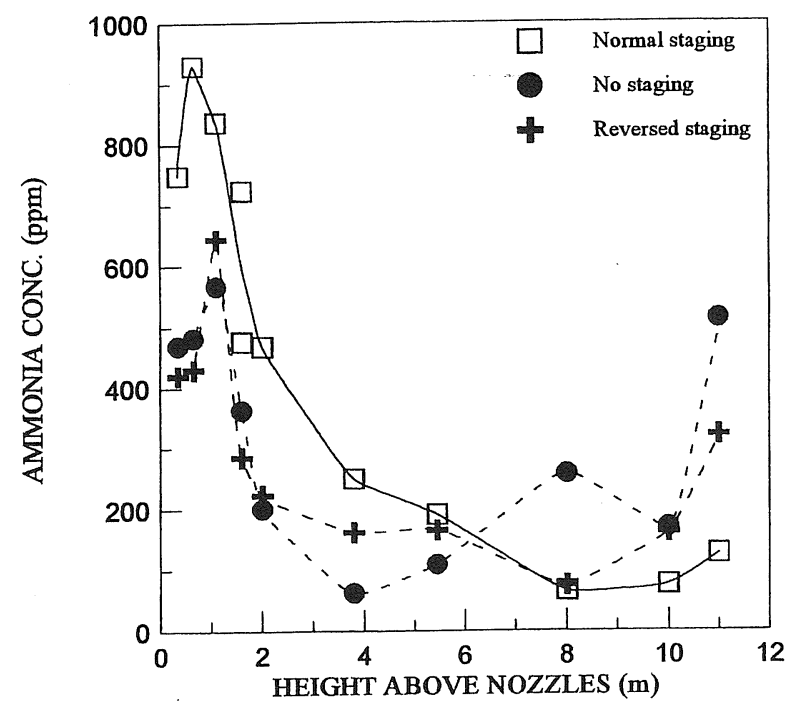

Fig.4 Concentration of ammonia as a function of height in the combustion chamber for the three air-staging cases. Analysed with FTIR. Spectral evaluation: PLS.

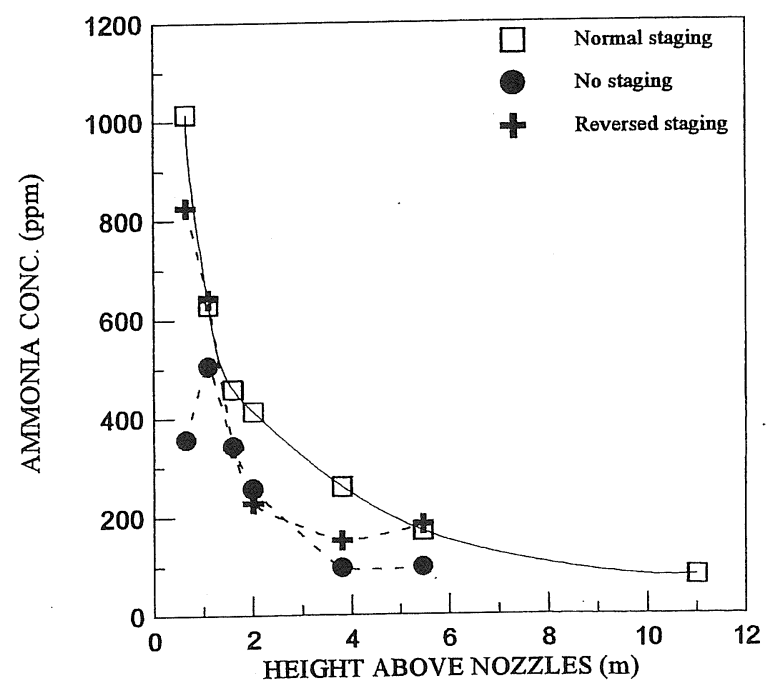

Fig.6 Concentration of ammonia as a function of height in the combustion chamber for the three air-staging cases. The gas-quenching probe (wet chemistry analysis).

\subsection{Comparison of the ammonia concentrations measured by the two probes}

Extracted gases in the gas-sampling probe were cooled to $200{ }^{\circ} \mathrm{C}$ and transported in a heated sampling line to an FTIR analyser, without any quenching. But when the GQ probe was used, $\mathrm{NH}_{3}$ was quenched by the circulating trapper solution sprayed through the distributor in the probe tip immediately behind the sintered quartz filter. Afterwards, the trapper solution was analysed for $\mathrm{NH}_{4}{ }^{+}$by wet chemistry.

This procedure changed the measurement conditions considerably. The result did not change however, as can be seen in Fig.7, where the $\mathrm{NH}_{3}$ concentrations measured by the two sampling systems are compared for the normal staging conditions. The GQ probe measurement shows a good correlation with the parallel FTIR measurement in almost every measurement position. The dependence of

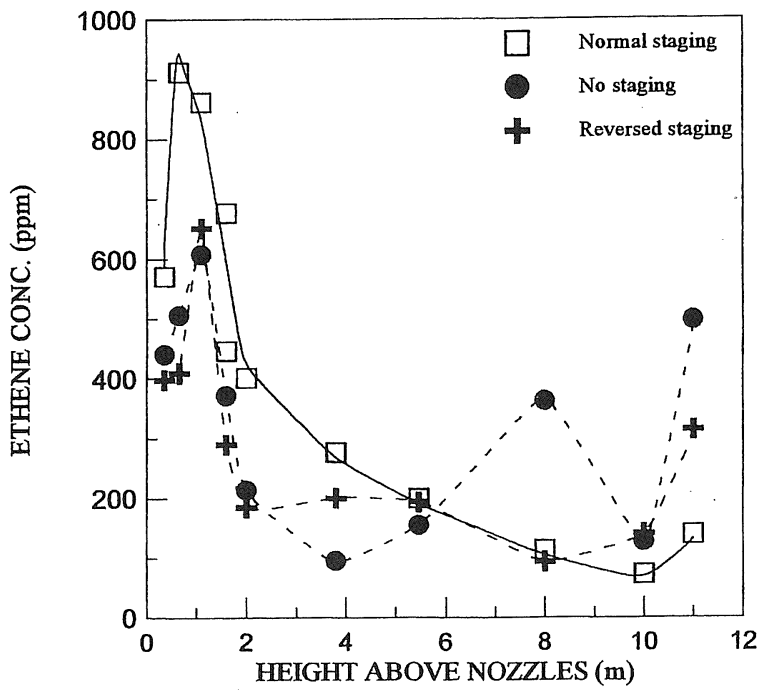

Fig.5 Concentration of ethene as a function of height in the combustion chamber for the three air-staging cases. Analysed with FTIR. Spectral evaluation: PLS.

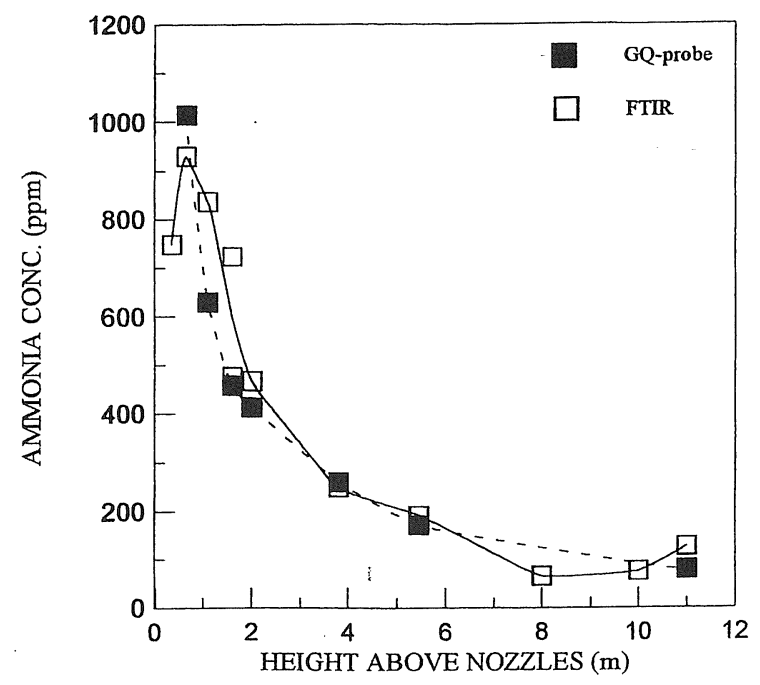

Fig.7 Comparison of the results of the measurement of ammonia with the gas-quenching probe (wet chemistry analysis) and the gas-sampling probe connected to the FTIR analyser. Operating conditions: normal air staging. Spectral evaluation method on FTIR: PLS. 
air-staging condition on the $\mathrm{NH}_{3}$ levels in the combustor is therefore confirmed by the two independent methods. Unfortunately, $\mathrm{NH}_{3}$ could not be measured in position $\mathrm{H} 1$ with the GQ probe, where the FTIR measurement always showed a lower result than in the $\mathrm{H} 2$ position. Such behaviour can be suspected, however, if the $\mathrm{NH}_{3}$ profiles are compared with the profiles for ethene, where also a lower concentration is measured in position $\mathrm{H} 1$ relative to $\mathrm{H} 2$ for all air-staging cases (Fig.5). The comparison in Fig.7 indicates that the gas-sampling probe, together with the FTIR and the GQ measurements, give reliable levels of $\mathrm{NH}_{3}$ in the combustion chamber.

\subsection{Comparison of the results for ammonia and ethene}

The concentration profiles for $\mathrm{NH}_{3}$ and ethene in Figs.4 and 5 have similar trends: large concentrations at the bottom of the combustor and falling concentration profiles from there upwards. It is striking that the changes in $\mathrm{NH}_{3}$ are followed by identical changes in $\mathrm{C}_{2} \mathrm{H}_{4}$, for example in the last measurement port $\mathrm{H} 13$, where both $\mathrm{NH}_{3}$ and $\mathrm{C}_{2} \mathrm{H}_{4}$ rose in all three operating cases. This port is at $10.9 \mathrm{~m}$, where the combustion gases flow towards the exit of the combustion chamber (Fig.1). The reason for the increase could be that excess amount of volatiles containing $\mathrm{NH}_{3}$ and $\mathrm{C}_{2} \mathrm{H}_{4}$ are present along the front wall, where the fuel is supplied. Close to the exit of the combustion chamber, this excess amount of volatiles is mixed with the centre flow containing fewer volatiles, and this leads to the observed rise in concentrations of $\mathrm{NH}_{3}$ and $\mathrm{C}_{2} \mathrm{H}_{4}$. The explanation given is supported by the fact that the observed increase of volatiles is larger for the two cases where no secondary air was supplied to the combustion chamber. Lack of secondary air leads to poorer mixing, and more primary air pushes the devolatilisation up to higher levels; both factors increase the volatile content along the front wall. If the volatiles entering the cyclone were not burned completely, emissions of $\mathrm{NH}_{3}$ and ethene from the boiler would occur. This requires to be investigated further.

\section{Discussion and conclusions}

The accuracy of the measurements by means of the improved GQ probe sampling system and the gas-sampling probe connected to an FTIR, is high enough to follow the influence of air-staging on the levels of $\mathrm{NH}_{3}$ and $\mathrm{C}_{2} \mathrm{H}_{4}$ in the combustion chamber of the boiler.

A comparison between the $\mathrm{NH}_{3}$ concentration profiles for the two probes using different sampling procedures showed almost identical results for $\mathrm{NH}_{3}$ during the three air-staging conditions. This can be explained in two ways: either the measurement is correct for both methods, or they are equally influenced by secondary reactions. However, it is not likely that two probes with different sampling procedures are influenced by the same secondary reactions during different air-staging conditions.
Nevertheless, an attempt to estimate the influence of potential secondary reactions with $\mathrm{NH}_{3}$ was performed in a simple plug-flow model. This will be the subject of a later paper.

$\mathrm{NH}_{3}$ and $\mathrm{C}_{2} \mathrm{H}_{4}$ follow each other closely in the combustion chamber in all three air-staging cases. The concentrations of $\mathrm{NH}_{3}$ and ethene increase towards the exit of the combustion chamber. This could be important for the emissions of hydrocarbons and $\mathrm{NH}_{3}$ from the boiler.

\section{Acknowledgement}

This work has been supported financially by the Swedish National Board for Technical and Industrial Development (NUTEK). The operation of the research equipment at the boiler by Abbas Zarrinpour and Hans Schmidt is gratefully acknowledged.

\section{References}

1 KILPINEN $\mathrm{P}$ and HUPA M. Homogeneous $\mathrm{N}_{2} \mathrm{O}$ chemistry at fluidized bed combustion conditions: a kinetic modeling study. Comb \& Flame, 1991, 85, pp 94-104.

2 TSUO Y Y P, LEE Y Y, RAINIO A and HYPPANENT. Three dimensional modeling of $\mathrm{N}_{2} \mathrm{O}$ and $\mathrm{NO}_{\mathrm{x}}$ emissions from circulating fluidized bed boilers. Proc 13th Int Conf on Fluidized Bed Combustion. The American Society of Mechanical Engineers, New York, 1995; pp 1059-1069.

3 HANNES J, RENZ U and VAN DEN BLEEK C M. The IEA model for circulating fluidized bed combustion. Proc 13th Int Conf on Fluidized Bed Combustion. The American Society of Mechanical Engineers, New York, 1995, pp 287-296.

4 VERLOOP C M, ANDRIES J and HEIN K R G. FT-IR technique, principle and experience. 6th Topic Oriented Technical Meeting, International Flame Research Foundation, Karlsruhe, Oct 1992.

5 JOHANSSON A, AXELSSON H and MELLQUIST J. Continous monitoring of ammonia by differential optical absorption spectroscopy (DOAS). Optical Sensing for Environmental Monitoring, Atlanta, Oct 1993.

6 HJULER K and DAM-JOHANSEN K. Design of a flue gas probe for ammonia measurement. Anal Chim Acta, 1993, 282, pp 703-709.

7 SMART J and MAALMAN T. An analytical procedure for the quantitative determination of $\mathrm{NH}_{3}$ and $\mathrm{HCN}$ in combustion systems. IFRF Doc No f 72/a /16, IJmuiden, 1987.

8 BOSE A C, DANNECKER K M and WENDT J O L. Coal combus tion effects on mechanism governing the destruction of $\mathrm{NO}$ and other nitrogenous species during fuel-rich combustion. Energy \& Fuels, 1988, 2, pp 301-308.

9 NIMMO W, RICHARDSON J and HAMPARTSOUMIAN E. The effect of fuel-nitrogen functionality on the formation of NO, $\mathrm{HCN}$ and $\mathrm{NH}_{3}$ in practical liquid-fuel flames. $J$ Inst Energy, 1995, 68, pp 170-177. 10 AHO M J, HÄÄMÄLÄINEN J P and TUMMAVOURI J L. Importance of solid fuel properties to nitrogen oxide formation through $\mathrm{HCN}$ and $\mathrm{NH}_{3}$ in small particle combustion. Comb and Flame, 1993, 95, pp 22-30.

11 MORITOMI H, HARADA M, FUJIWARA N, HIRAMA T and OKAZAKI K. Influence of fluidization on $\mathrm{N}_{2} \mathrm{O}$ emissions from coal combustion. 5th China-Japan Symposium on Fluidized Beds, Nagoya, 1994.

12 AMAND L-E. Nitrous oxide emission from circulating fluidized bed combustion. Doctoral thesis, Dept of Energy Conversion, Chalmers University of Technology and University of Gothenburg, Gothenburg, 1994.

13 KASSMAN H, ABUL-MILH M and AMAND L-E. Measurement of $\mathrm{NH}_{3}$ and $\mathrm{HCN}$ concentrations in a CFB boiler: a comparison between a conventional absorption and FTIR technique. Proc 13th Int Conf on Fluidized Bed Combustion, The American Society of Mechanical Engineers, New York, 1995, pp 1447-1454.

14 ÅMAND L-E and LECKNER B. Formation of $\mathrm{N}_{2} \mathrm{O}$ in a circulating fluidized-bed boiler, Energy \& Fuels, 1993, 7, pp 1097-1107. 
15 LYNGFELT A, ÅMAND L-E, KARLSSON M and LECKNER B. Reduction of $\mathrm{N}_{2} \mathrm{O}$ emissions from fluidized bed combustion by reversed air staging. Proc 2nd Int Conf on Combustion and Emissions Control, Institute of Energy, London, 1995, pp 89-100.

16 LYNGFELT A, ÅMAND L-E and LECKNER B. Low $\mathrm{N}_{2} \mathrm{O}$, NO and $\mathrm{SO}_{2}$ emissions from fluidized bed boilers. Proc 13th Int Conf on Fluidized Bed Combustion, The American Society of Mechanical Engineers, New York, 1991, pp 1049-1057.

17 Galactic Industries Corp. Spectra Calc, Version 2.21, 1989.
18 KARLSSON M and ÅMAND L-E. FTIR analysis of ammonia and ethene in a fluidized bed combustion chamber. Proc 3rd Nordic SOx-NOx Conference, CHEC Rep. No.9610, Dept of Chem Eng, Technical University of Denmark, Lyngby, 1996, pp 93-97.

19 KASSMAN H. Measurement of ammonia and trace metals in fluidised bed combustion. Licentiate thesis, Dept of Inorganic Chemistry, Chalmers University of Technology and University of Gothenburg, Gothenburg, 1995.

(Paper received June 1996.) 